\title{
Rytm z szerokimi zespołami QRS - trudności diagnostyczne
}

\author{
Rhythm with wide QRS - difficulty in interpreting
}

\author{
Grzegorz Karkowski ${ }^{1}$, Marcin Kuniewicz ${ }^{1}$, Andrzej Ząbek ${ }^{1}$, Jacek Bednarek ${ }^{1}$, Jacek Lelakowski ${ }^{1{ }^{12}}$ \\ ${ }^{1}$ Oddział Kliniczny Elektrokardiologii Krakowskiego Szpitala Specjalistycznego im. Jana Pawła II w Krakowie \\ ${ }^{2}$ Instytut Kardiologii Collegium Medicum Uniwersytetu Jagiellońskiego w Krakowie
}

\section{Streszczenie}

Przedstawiono trudności w interpretacji rytmu z szerokimi zespołami QRS u 25-letniej pacjentki z preekscytacją komór oraz okresowo występującym przyspieszonym rytmem z szerokimi zespołami QRS (94/min), spełniającym w elektrokardiogramie (EKG) morfologiczne kryteria rytmu komorowego, bez poprzedzających załamków P. Wstępne trudności w interpretacji EKG wyjaśniło wykonane badanie elektrofizjologiczne, w którym wykazano nadkomorowe pochodzenie rytmu przewodzonego do komór przez drogę dodatkową. Wykonanie ablacji prądem o częstotliwości radiowej drogi dodatkowej odsłoniło okresowo występujący rytm dolno-przedsionkowy pochodzący z okolic mięśniówki zatoki wieńcowej. Bliskie sąsiedztwo rytmu przedsionkowego i drogi dodatkowej skutkowało natychmiastowym przewodzeniem do komór, doskonale imitując rytm komorowy. Opisany przypadek zwraca uwagę na potrzebę uwzględnienia rytmu pozazatokowego z preekcytacją komór w toku diagnostyki rytmu z szerokimi zespołami QRS.

Słowa kluczowe: preekscytacja, ablacja, rytm o szerokich zespołach QRS

(Folia Cardiologica 2015; 10, 2: 122-126)

\section{Wstęp}

Ablacja prądem o częstotliwości radiowej (RF, radio frequency) drogi dodatkowej u pacjentów bez objawów pozostaje tematem wielu debat i nadal brakuje jednoznacznego stanowiska, czy powinna być wykonywana, a jeśli tak, to czy u wszystkich pacjentów. Według wytycznych American College of Cardiology/ American Heart Association/ European Society of Cardiology (ACC/AHA/ESC) z 2003 roku ablację RF powinno się rozważyć w tej grupie pacjentów (klasa zaleceń Ila B) [1]. W ostatnim konsensusie ekspertów Pediatric and Congenital Electrophysiology Society/ / Heart Rhythm Society (PACES/HRS) [2], dotyczącym ablacji u niewykazujących objawów młodych pacjentów (8-21 lat) z preekscytacją komór, jego autorzy uważają, że ablacja powinna być rozważona u tych osób, u których występują migotania przedsionków z cyklem komór poniżej 250 ms. Przed podjęciem decyzji o ablacji rozsądne wydaje się uwzględnienie czynników związanych z wyższym ryzykiem wystąpienia migotania komór, tj. takich jak występowanie objawowych częstoskurczów nadkomorowych, obecność szlaków przegrodowych, mnogie szlaki, krótki okres refrakcji (250-270 ms) czy płeć męska. W przypadku ablacji szlaków lewostronnych wykonuje się zarówno dojście transaortane (wsteczne), jak i transseptalne. Każda z metod ma swoje wady i zalety, charakteryzując się podobną skutecznością oraz ryzykiem powikłań.

W niniejszej pracy, na podstawie przypadku klinicznego, przedstawiono trudności diagnostyczne w różnicowaniu przyspieszonego rytmu komorowego z jawnym zespołem preekscytacji komór w zapisie elektrokardiograficznym (EKG).

Adres do korespondencji: lek., mgr inż. Andrzej Ząbek, Oddział Kliniczny Elektrokardiologii, Krakowski Szpital Specjalistyczny im. Jana Pawła II, ul. Prądnicka 80, 31-202 Kraków, e-mail: andrzej_j_z@poczta.onet.pl 


\section{Opis przypadku}

Pacjentka w wieku 25 lat, z podejrzeniem preekscytacji komór, została przyjęta na oddział w celu wykonania badania elektrofizjologicznego oraz ewentualnej ablacji metodą RF. W zapisie EKG w dniu przyjęcia zarejestrowano rytm 94/min (długość cyklu 640 ms) z szerokimi zespołami QRS o morfologii bloku prawej odnogi pęczka Hisa (RBBB, right bundle branch block) (QRS $160 \mathrm{~ms}$ ), bez widocznych załamków P (ryc. 1). W wywiadzie występowały okresowo nietypowe kołatania serca, jednak nie udało się uzyskać zapisu EKG tej arytmii. W dostarczonym przez pacjentkę zapisie z 24-godzinnego badania EKG metodą Holtera zarejestrowano w początkowej części (pierwsze 6 pobudzeń) rytm prawdopodobnie zatokowy, z odstępem PQ wynoszącym 100-110 ms, z falą delta na ramieniu wstępującym zespołów QRS (szerokość QRS 120 ms), a następnie po zwolnieniu rytmu przedsionków (do 51/min) występowało stopniowe nakładanie się poszerzonych zespołów QRS (QRS $160 \mathrm{~ms}$ ) na załamki P. Pierwszy szeroki zespół QRS (QRS $160 \mathrm{~ms}$ ) jest zatem poprzedzany załamkiem P, a następne kolejne szerokie zespoły QRS już nie są poprzedzane przez załamki P (ryc. 2).

W wykonanym badaniu echokardiograficznym u pacjentki nie stwierdzono istotnych nieprawidłowści. Jako następne przeprowadzono badanie elektrofizjologicze (EPS, electrophysiology study), w trakcie którego nie obserwowano rytmu z szerokimi zespołami QRS widocznego na rycinie 1. Wykazano obecność drogi dodatkowej o lokalizacji lewostronnej bocznej, o okresie refrakcji wynoszącym $280 \mathrm{~ms}$. W trakcie stopniowanej stymulacji przedsionkowej uwidoczniono nasilające się cechy preekscytacji komór, które przy cyklu 370 ms osiągały maksymalne nasilenie, a morfologia zespołów QRS odpowiadała morfologii zespołów komorowych widocznych w EKG przy przyjęciu (pełna preekcytacja) (ryc. 3). Tłumaczy to fakt, że czas od piku stymulacji do aktywacji komór w zapisie z powierzchniowego EKG przy przewodzeniu przez szlak dodatkowy wynosi około 120 ms. Po wykonaniu ablacji RF drogi dodatkowej w trakcie stopniowanej stymulacji przedsionkowej przy cyklu stymulacji przedsionków 370 ms przewodzenie do komór odbywa się przez drogę wolną i wynosi 260 ms, co sugeruje, że przed wykonaniem ablacji przy cyklu stymulacji przedsionków 370 ms łącze przedsionkowo-komorowe bierze znikomy udział w aktywacji komór. Nie stwierdzono cech przewodzenia wstecznego przez drogę dodatkową. W trakcie badania EPS nie wyindukowano żadnej arytmii. Z dojścia transaortalnego wykonano ablację RF drogi dodatkowej. Po tym zabiegu w zapisach EKG uwidocznił się rytm dolnoprzedsionkowy przewodzony do komór drogą fizjologiczną (wąskie zespoły QRS 80 ms) (ryc. 4).

\section{Dyskusja}

W opisanym przypadku w różnicowaniu przyspieszonego rytmu z szerokimi zespołami QRS należy uwzględnić

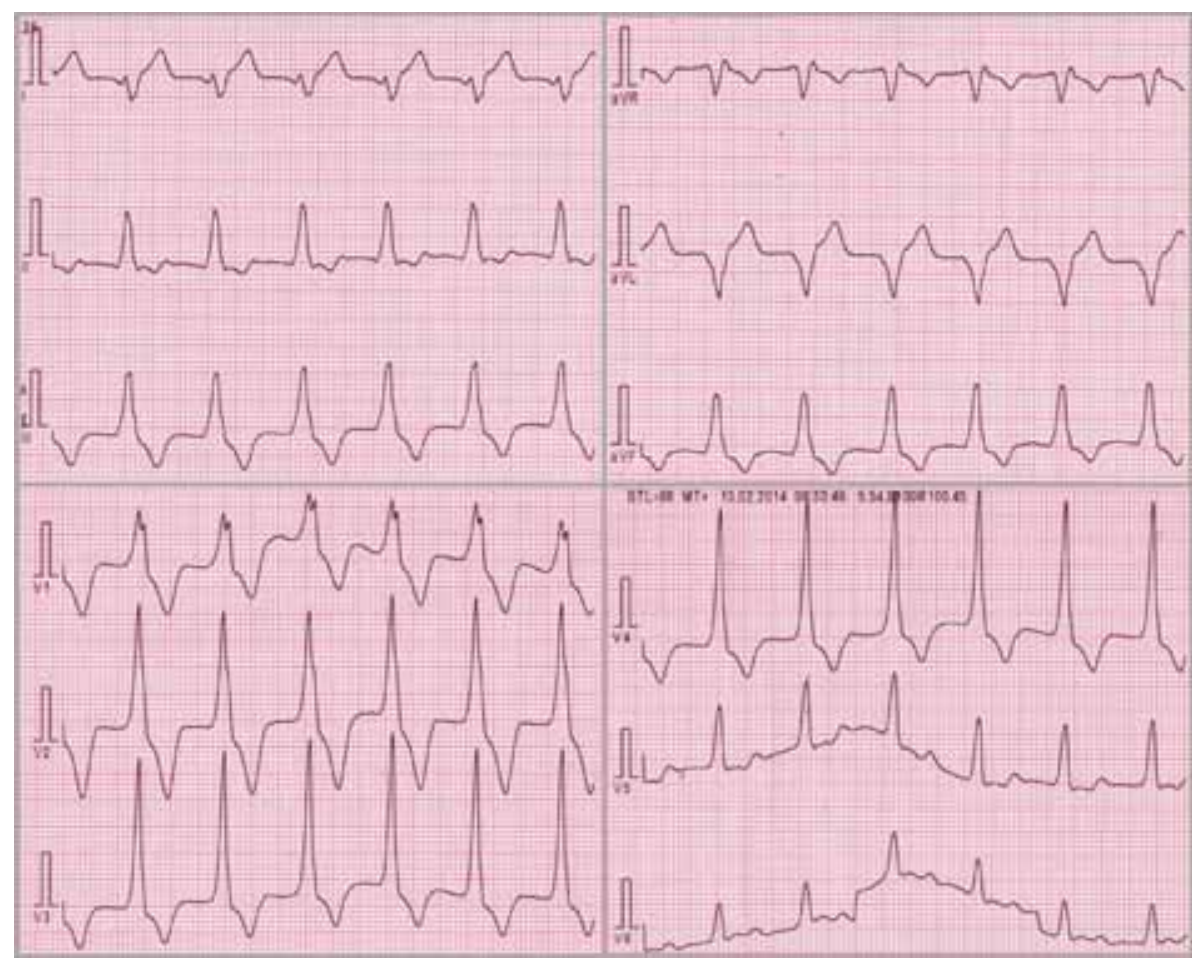

Rycina 1. Zapis elektrokardiograficzny przy przyjęciu - rytm z szerokimi zespołami QRS 


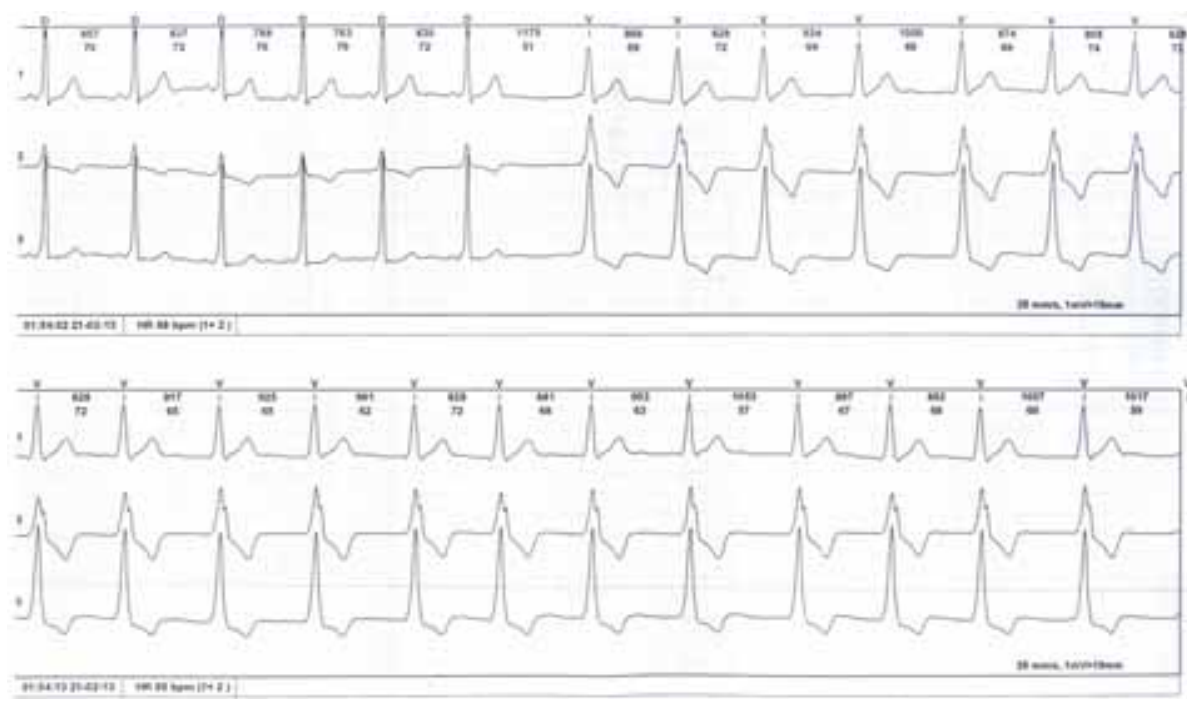

Rycina 2. Fragment zapisu z 24-godzinnego monitorowania elektrokardiograficznego metodą Holtera

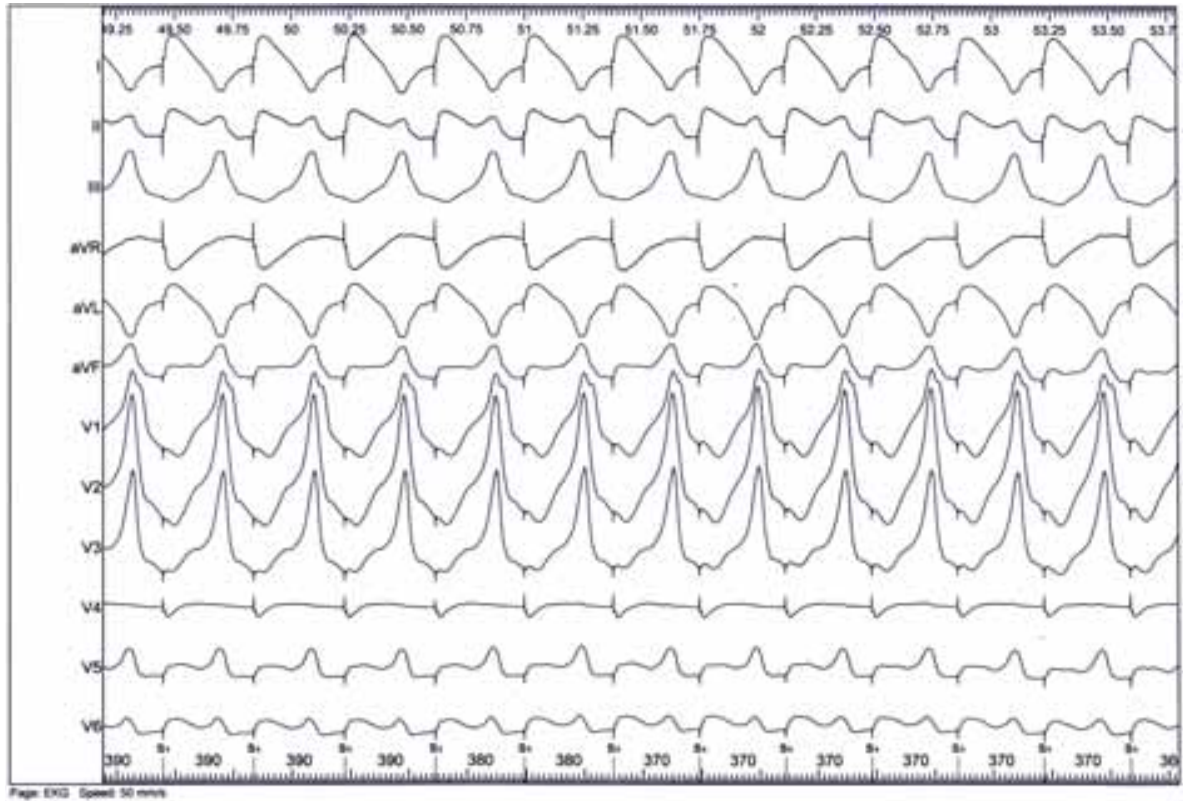

Rycina 3. Zapis elektrokardiograficzny podczas stopniowanej stymulacji przedsionka w trakcie badania elektrofizjologicznego

przyspieszony rytm komorowy, rytm zatokowy lub węzłowy z preekscytacją komór albo aberracją śródkomorową oraz stymulację z rozrusznika serca (w trybie bipolarnym - bez „pików” stymulacji). W zapisie EKG przy przyjęciu (ryc. 1), ze względu na brak poprzedzających zespołów QRS załamków $P$, rozpoznanie rytmu zatokowego wydaje się mało prawdopodobne. Morfologia zespołów QRS spełnia niektóre kryteria morfologiczne rytmu komorowego wskazujące na mięsień komory jako miejsce pochodzenia rytmu. Zarejestrowano brak załamków $\mathrm{P}$ poprzedzających szerokie zespoły QRS o czasie trwania 160 ms i morfologii RBBB z prawogramem patologicznym (charakterystyczne zazębienie QRS Rr' w odprowadzeniu V1, R > r' - „uszy królika”). Dodatkowo we wszystkich odprowadzeniach przedsercowych występowało dodatnie wychylenie zespołów QRS (dodatnia zgodność wychylenia w odprowadzeniach przedsercowych). Stosując algorytm Vereckei i wsp. [3], uwzględniający szybkość narastania depolaryzacji w początkowym oraz końcowym okresie depolaryzacji komór, można podejrzewać, że ma się do czynienia z rytmem komorowym $(\mathrm{Vi} / \mathrm{Vt}<1)$ [4]. 


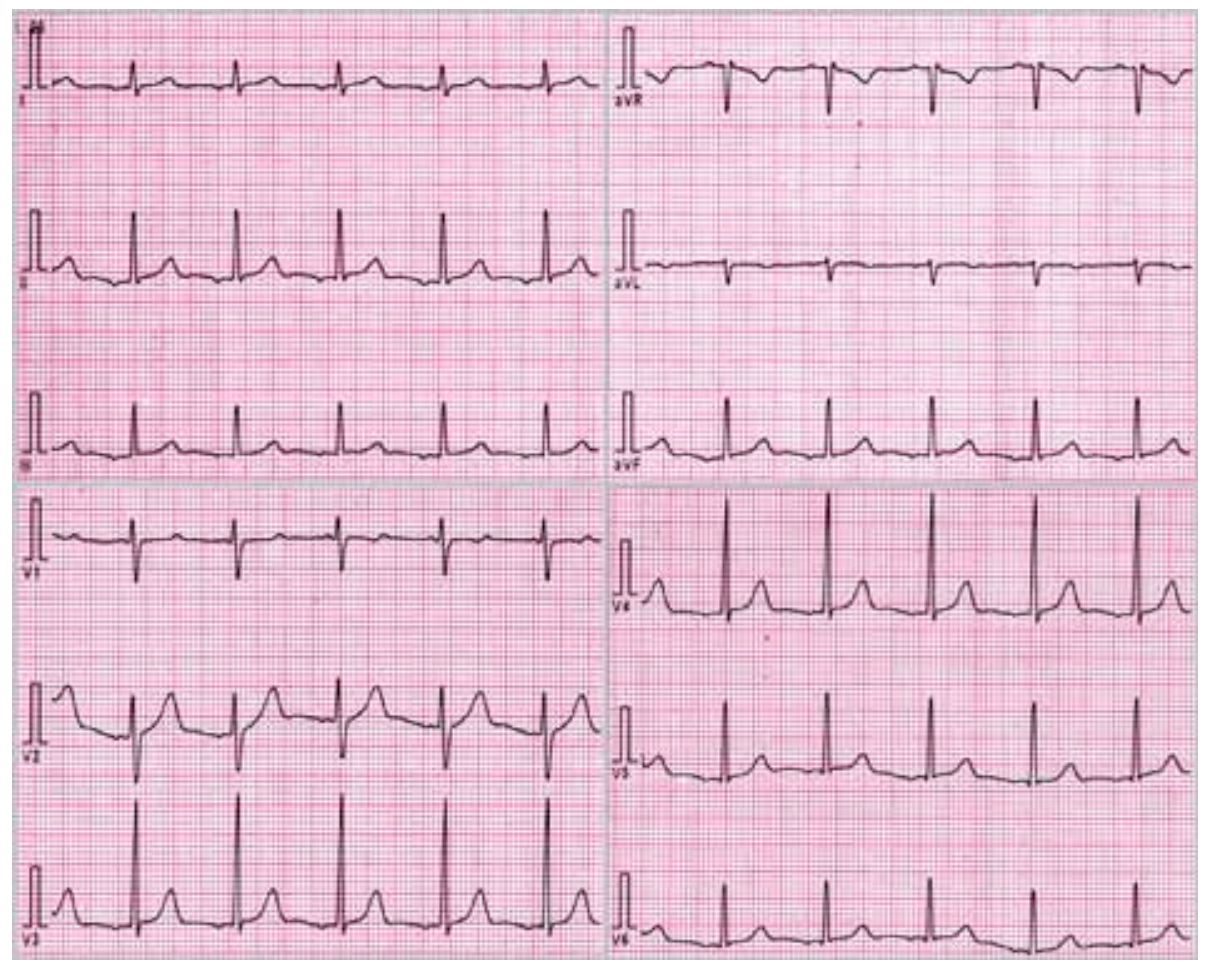

Rycina 4. Zapis elektrokardiograficzny wykonany po ablacji prądem o częstotliwości radiowej drogi dodatkowej ukazujący obecność pozazatokowego rytmu przedsionkowego

W celu różnicowania częstoskurczu komorowego i nadkomorowego przebiegającego z preekscytacją można użyć algorymu Brugady [5]. Cechami mającymi wskazywać na komorowy charakter arytmii były obecność dominującej ujemnej polaryzacji zespołów QRS w odprowadzeniach przedsercowych V4-V6, obecność zespołów QS w co najmniej jednym odprowadzeniu przedsercowym V2-V6 oraz inny niż 1:1 stosunek rytmu komór do rytmu przedsionków. W opisanym przypadku wymienionych kryteriów nie dostrzeżono.

W początkowej części rytmu o szerokich zespołach QRS (QRS 160 ms) w badaniu EKG metodą Holtera zarejestrowano cechy wskazujące na obecność nasilonej preekscytacji komór, tj. pierwszy szeroki zespół QRS (QRS 160 ms) poprzedzał załamek P, co mogło sugerować nasilenie preekcytacji komór. Jednak kolejne szerokie zespoły QRS przestają być poprzedzone załamkami P, co jest charakterystyczne dla przyspieszonego rytmu komorowego.

Odpowiedzi dostarczyło EPS, w którym wykazano obecność drogi dodatkowej. Morfologia zespołów QRS maksymalnej preeksytacji komór podczas stymulacji przedsionka odpowiadała morfologii klinicznego rytmu z szerokimi zespołami QRS zarejestrowanego przy przyjęciu. Porównując morfologie zespołów QRS podczas stopniowanej stymulacji przedsionków oraz podczas rytmu z szerokimi zespołam QRS, zauważono różnice, które według autorów wynikały w znacznym stopniu z ograniczeń technicznych (porównanie zapisów z dwóch różnych systemów, tj. z aparatu EKG oraz z systemu elektrofizjologicznego BARD, dodatkowo po impulsach stymulacji w systemie elektrofizjologicznym widoczne artefakty, niskowoltażowy zapis w odprowadzeniu V4, aVR - artefakty), co nie zmieniło faktu, że zapisy były istotnie podobne.

Zapis EKG wykonany po ablacji wyjaśnił przyczynę trudności w interpretacji elektrokardiograficznej. Morfologia okresowo uruchamiającego się rytmu przedsionkowego wskazuje na ognisko znajdujące się w mięśniówce zatoki wieńcowej [6]. Ognisko to jest usytuowane w bliskim sąsiedztwie drogi dodatkowej i w związku z tym bodźce sa szybko w całości bezpośrednio przewodzone do komór w zapisie EKG występuje pełna preekscytacja komór (QRS 160 ms), a załamek P jest „schowany” w poszerzonym zespole QRS.

\section{Podsumowanie}

Opisany przypadek zwraca uwagę na potrzebę uwzględnienia rytmu pozazatokowego z preekcytacja komór w toku diagnostyki rytmu z szerokimi zespołami QRS. 


\section{Abstract}

In the case described we demonstrate the difficulty in interpreting the rhythm with wide QRS complex. The 25 year old patient with ventricular pre-excitation and periodically occurring rhythm with wide QRS complex, morphology meets the electrocardiographic (ECG) criteria for ventricular arrhythmias and in the absence of $P$ waves. Initial difficulties in the interpretation of ECG were explained by electrophysiological study in which we demonstrate the supraventricular origin of rhythm conducted to the ventricles with pre-excitation. Radio frequency ablation of the accessory pathway reveals the periodically occurring low-atrial rhythm originating in the muscle of the coronary sinus. Very close proximity of the atrial rhythm and the accessory pathway resulted instant conduction of impulse to the ventricle and cause perfect imitation of ventricular rhythm. This case draws attention on the need to take account of none-sinus rhythm with ventricular preexcitation during diagnosis of rhythm with wide QRS complex.

Key words: pre-excitation, ablation, broad QRS complex rhythm

(Folia Cardiologica 2015; 10, 2: 122-126)

\section{Piśmiennictwo}

1. Blomstrom-Lundqvist C., Scheinman M.M., Aliot E.M. i wsp. ACC/AHA/ /ESC guidelines for the management of patients with supraventricular arrhythmias - executive summary: a report of the American College of Cardiology/American Heart Association Task Force on Practice Guidelines and the European Society of Cardiology Committee for Practice Guidelines (Writing Committee to Develop Guidelines for the Management of Patients With Supraventricular Arrhythmias). Circulation 2003; 108: 1871-1909.

2. Cohen M.I., Triedman J.K., Cannon B.C. i wsp. PACES/HRS expert consensus statement on the management of the asymptomatic young patient with a Wolff-Parkinson-White (WPW, ventricular preexcitation) electrocardiographic pattern: developed in partnership between the Pediatric and Congenital Electrophysiology Society (PACES) and the Heart Rhythm Society (HRS). Endorsed by the governing bodies of PACES, HRS, the American College of Cardiology Foundation (ACCF), the American Heart Association (AHA), the American Academy of Pediatrics (AAP), and the Canadian Heart Rhythm Society (CHRS). Heart Rhythm 2012; 9: 1006-1024.

3. Vereckei A. Current algorithms for the diagnosis of wide QRS complex tachycardias. Curr. Cardiol. Rev. 2014; 10: 262-276.

4. Vereckei A., Duray G., Szenasi G. i wsp. Application of a new algorithm in the differential diagnosis of wide QRS complex tachycardia. Eur. Heart J. 2007; 28: 589-600.

5. Brugada P., Brugada J., Mont L. i wsp. A new approach to the differential diagnosis of a regular tachycardia with a wide QRS complex. Circulation 1991; 83: 1649-1659.

6. Badhwar N., Kalman J.M., Sparks P.B. i wsp. Atrial tachycardia arising from the coronary sinus musculature: electrophysiological characteristics and long-term outcomes of radiofrequency ablation. J. Am. Coll. Cardiol. 2005; 46: 1921-1930.

\section{Komentarz}

\section{dr n. med. Michał Chudzik}

Klinika Elektrokardiologii Uniwersytetu Medycznego w Łodzi

Autorzy tej pracy poruszyli bardzo istotny problem kliniczny różnicowania częstoskurczu z szerokimi zespołami QRS. Obecnie najczęściej stosuje się następujące algorytmy: Brugady, Bayesiana, Griffitha, algorytm aVR i kryterium lead II R-wave-peak-time (RWPT). Po raz pierwszy w sposób bezpośredni czułość i specyficzność tych algorytmów w swej publikacji porównali Jastrzębski i wsp. [1], wykazując, że żaden z nich nie zapewnia bezbłędnej diagnostyki pochodzenia arytmii na podstawie zapisu elektrokardiograficznego (EKG). Wszystkie pięć algorytmów wykazywało zbliżoną dokładność diagnostyczną, choć w przypadku RWPT była mniejsza niż algorytmu Brugady $(68,8$ v. 77,5\%; $p=0,04)$. Czułość tych algorytmów wynosiła odpowiednio: RWPT - 60\%, Brugady - 89\%, Griffitha - 94,2\%, Bayesiana - 89\%, natomiast specyficzność: Griffitha - 39,8\%, RWPT - 82,7\%, Brugady - 59,2\%, Bayesiana - 52,0\%. Natomiast współczynnik prawdopodobieństwa poszczególnych algorytmów wynosił odpowiednio: RWPT - 3,46, Brugady - 2,18, Bayesiana - 1,86, aVR - 1,67, Griffitha - 1,56.

Zestawienie czułości i specyficzności poszczególnych algorytmów jest zatem następujące:

- algorytm RWPT (R-wave-peak-time) w odporowadzeniu II [3]: 60\% i 82,7\%;

- algorytm aVR [4]: 87,1\% i 48\%;

- algorytm Bayesiana [5]: 89\% i 52\%;

- algorytm Griffitha [6]: 94,2\% i 39,8\%. 


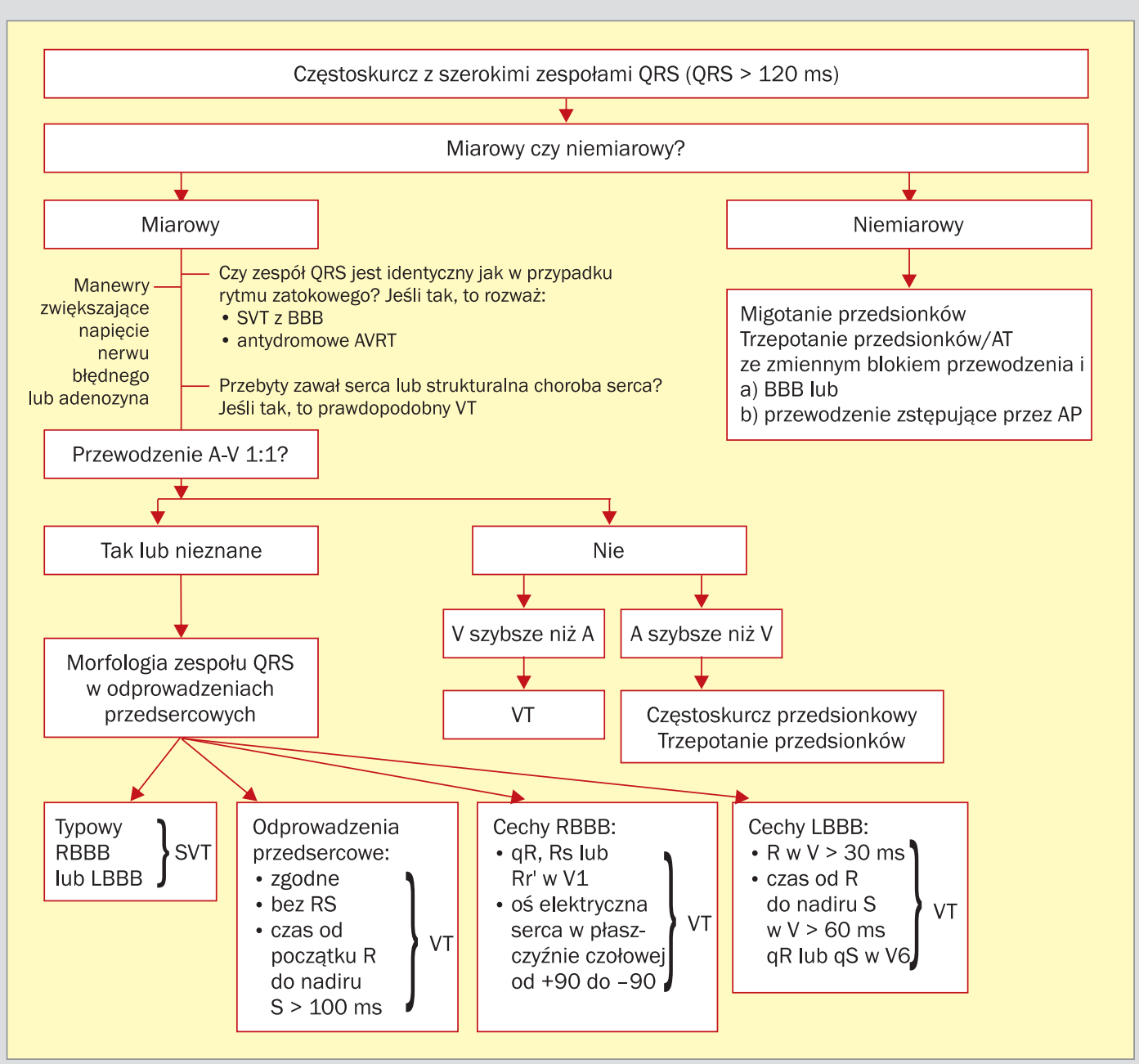

Rycina 1. Różnicowanie częstoskurczów z szerokimi zespołami QRS według wytycznych American College of Cardiology/American Heart Association/European Society of Cardiology (ACC/AHA/ESC) (na podstawie [7]); BBB (bundle branch block) - blok odnogi pęczka Hisa; AVRT (atrioventricular reciprocating tachycardia) - częstoskurcz przedsionkowo-komorowy związany z obecnością drogi dodatkowej; VT (ventricular tachycardia) - częstoskurcz komorowy; AP (atrial pacing) - stymulacja przedsionkowa; AV (atrio-ventricular) - przedsionkowo-komorowy; RBBB (right bundle branch block) - blok prawej odnogi pęczka Hisa; SVT (supraventricular tachycardia) - częstoskurcz nadkomorowy; LBBB (left bundle branch block) - blok lewej odnogi pęczka Hisa

Widać zatem, że najczęściej wykorzystywany w praktyce klinicznej algorytm Brugady również ma swoje ograniczenia. Nie należy też zapominać o opublikowanym w 2003 roku przez American College of Cardiology/ American Heart Association/European Society of Cardiology (ACC/AHA/ESC) bardzo przydatnym, opatrzonym wieloma wskazówkami klinicznymi, algorytmie różnicowania pochodzenia arytmii (ryc. 1) [7].

W tym przypadku algorytm ten byłby zawodny, ponieważ przy arytmii z morfologią prawej odnogo pęczka Hisa (RBBB, right bundle branch block) obraz w odprowadzeniu V1 Rr' wskazuje na częstoskurcz komorowy (VT, ventricular tachycardia). Natomiast algorytm Brugady u chorych z morfologią RBBB w tym przypadku nie spełniałby punktów 1. i 3. w tabeli (tab. 1). Jednocześnie nie ma też morfologii RBBB, które mogłoby jednoznacznie wskazać na częstoskurcz nadkomorowy (SVT, supraventricular ventricular tachycardia).

W 2010 roku Joseph Brugada wprowadził nowe kryterium różnicujące VT od SVT. Analiza opiera się na pomiarze w Il odprowadzeniu kończynowym czasu trwania odstępu od początku zespołu QRS do najniższego poziomu załamka Q lub szczytu R. Jeżeli czas ten jest dłuższy niż $50 \mathrm{~ms}$, to jest to VT. W opisywanym przypadku w II odprowadzeniu widać mały załamek Q o krótszym czasie trwania tego odstępu niż zalecane w tym kryterium 50 ms, zatem nie można 
Tabela 1. Różnicowanie częstoskurczów z szerokim QRS z morfologią RBAAA

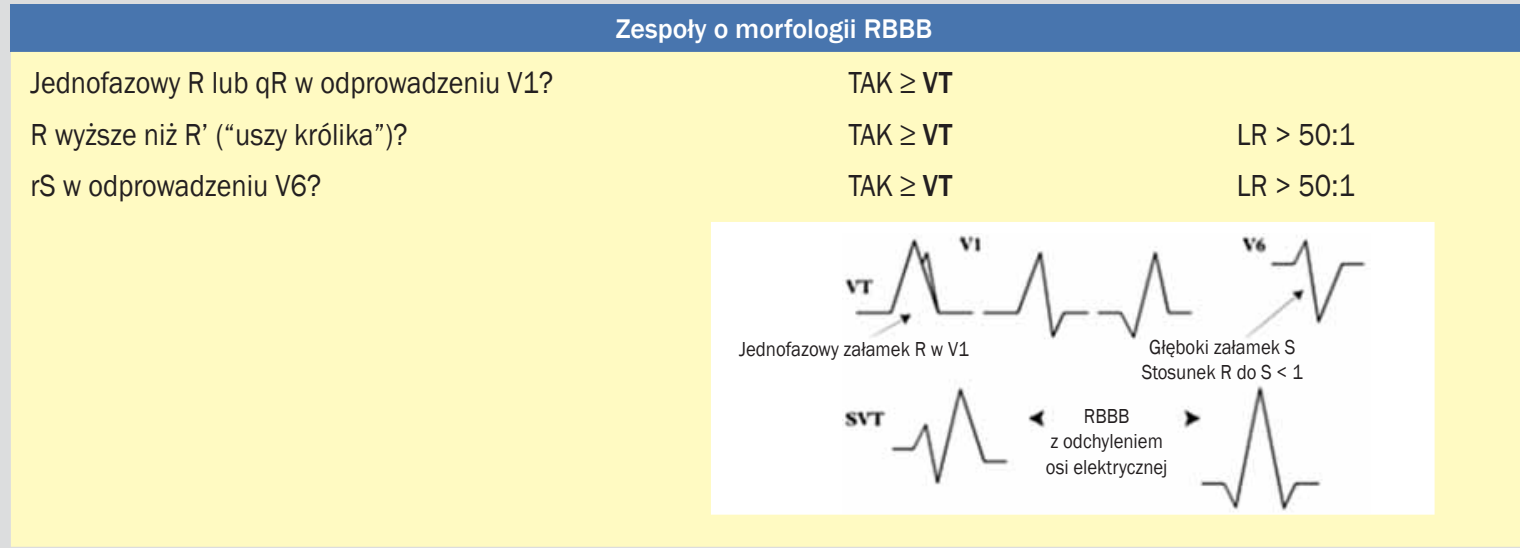

RBBB (right bundle branch block) - blok prawej odnogi pęczka Hisa; VT (ventricular tachycardia) - częstoskurcz komorowy; SVT (supraventricular tachycardia) - częstoskurcz nadkomorowy

zdiagnozować VT. Griffith z kolei do rozpoznania SVT u chorych z arytmią o morfologii RBBB sugeruje obecność zespołów rSR w odprowadzeniu V1 i R/S w odprowadzeniu V6 oraz R wyższe niż S. U opisywanego pacjenta to kryterium nie zostałoby spełnione.

Jak zatem widać, co wykazali Jastrzębski i wsp., wszystkie algorytmy nie są pozbawione swoich ograniczeń. Warto korzystać z kilku w celu lepszego różnicowania arytmii, ale bardzo często o rozpoznaniu i skutecznej metodzie terapii będzie decydował wynik inwazyjnego badania elektrofizjologicznego.

\section{Piśmiennictwo}

1. Jastrzebski M., Kukla P., Czarnecka D. i wsp. Comparison of five electrocardiographic methods for differentiation of wide QRS-complex tachycardias. Europace 2012; 14: 1165-1171.

2. Brugada P., Brugada J., Mont L. i wsp. A new approach to the differential diagnosis of a regular tachycardia with a wide QRS complex. Circulation 1991; 83: 1649-59.

3. Pava L.F., Perafán P., Badiel M. i wsp. R-wave peak time at DII: a new criterion for differentiating between wide complex QRS tachycardias. Heart Rhythm 2010; 7: 922-926.

4. Vereckei A., Duray G., Szénási G. i wsp. Application of a new algorithm in the differential diagnosis of wide QRS complex tachycardia. Eur. Heart J. 2007; 28: 589-600.

5. Lau E.W., Pathamanathan R.K., Ng G.A. i wsp. The Bayesian approach improves the electrocardiographic diagnosis of broad complex tachycardia. Pacing Clin. Electrophysiol. 2000; 23 (10 Pt 1) 1519-1526.
6. Griffith M.J., Garratt C.J., Mounsey P. i wsp. Ventricular tachycardia as default diagnosis in broad complex tachycardia. Lancet 1994; 343: 386-388.

7. Blomström-Lundqvist C., Scheinman M.M., Aliot E.M. i wsp. ACC/ /AHA/ESC guidelines for the management of patients with supraventricular arrhythmias - executive summary. a report of the American college of cardiology/American heart association task force on practice guidelines and the European society of cardiology committee for practice guidelines (writing committee to develop guidelines for the management of patients with supraventricular arrhythmias) developed in collaboration with NASPE-Heart Rhythm Society. J. Am. Coll. Cardiol. 2003; 42: 1493-1531. 